(昭和 56 年 11 月 14 日受理)

\title{
Correlation between Some Mechanical and Physical Properties of Polycrystalline Graphites
}

\author{
S. Yoda and K. Fujisaki \\ Department of High Temperature Engineering, \\ Japan Atomic Energy Research Institute, \\ Tokai-mura, Ibaraki-ken, 319-11 Japan
}

\begin{abstract}
Mechanical and physical properties of polycrystalline graphites, tensile strength, compressive strength, flexural strength, Young's modulus, thermal expansion coefficient, electrical resistivity, volume fraction of porosity, and graphitisation were measured for ten brand graphites. Correlation between the mechanical and physical properties of the graphites were studied. Young's modulus and thermal expansion coefficient of the graphites depend on volume fraction of porosity. The Young's modulus of the graphites tended to increase with increasing the thermal expansion coefficient. For an anisotropic graphite, an interesting relationship between the Young's modulus $E$ and the thermal expansion coefficient $\alpha$ was found in any specimen orientations; $\alpha E=$ constant. The value of $\alpha E$ was dependent upon the volume fraction of porosity. It should be noted here that the electrical resistivity increased with decreasing grain size. The flexural and the compressive strength were related with the volume fraction of porosity while the tensile strength was not. The relationships between the tensile, the compressive and the flexural strength can be approximately expressed as linear functions over a wide range of the stresses.
\end{abstract}

\section{1. 緒}

言

多結晶黒鉛材料の機械的, 物性的性質は, その原料抒 よび製造法に著しく影響される。乙れは, 原料および製 造法の相違により黒鉛材料の内部組織, すなわち黒鉛化 度 $^{1,2)}$, 結晶粒度, 配向性, 気孔率 ${ }^{3,4)}$ 等が異なることに 起因する。そしててれら微視的因子が, 多結晶黒鉛材料 の巨視的性質を決定する重要な因子となる。したがって これら諸物性に及ぼす効果を正しく把握することは黒鉛 材料の機械的, 物理的性質を理解するために極めて重要 となる。

本研究は, 10 種黒鉛銘柄の機械的, 物理的性質, すな わち, 引張強度, 圧縮強度, 曲げ強度, ヤング率, 熱膨 張係数, 電気抵抗などを詳細に調べ, 上記因子の諸物性 に及ぼす影響，および諸物性間の相互関係について検討

\footnotetext{
*日本原子力研究所高温工学部： $\bar{T} 319-11$ 茨城県東海
} 村
した結果をまとめたあのである。

\section{2. 実験方法}

今回の実験に用いた黒鉛銘柄をTable I に示す。表中 の IG-11 (R) と IG-11 (S)は同一銘柄であり，（） 内の Rは素材ブロックの形状が円柱状， $\mathrm{S}$ は角状である ことを示している。これらの銘柄から以下に述べる各種 試験の試料を採取した。なお Table I には黒鉛材料の銘 柄別に記号を付した。乙の記号をむっててれ以後の結果 を表わすとととする。

\section{1 曲げ, 引張, 圧縮試験}

てれらの試験はすべてインストロン型引張試験機を用 いて行なった。試験片形状は曲げ試験片が $6 \phi \times 60 \mathrm{~mm}$, 引張試験片がゲージ部で $6 \phi \times 20 \mathrm{~mm}$, 圧縮試験片が $6 \phi$ $\times 12 \mathrm{~mm}$ である。曲げ試験は 4 点曲げで行なった。なお スパンの距離は, 内スパン $19.6 \mathrm{~mm}$, 外スパン $38.2 \mathrm{~mm}$ であり, クロスヘッドの速度は $0.5 \mathrm{~mm} / \mathrm{min}$ である。引 
Table I Various graphite materials used in the experiments.

\begin{tabular}{|l|l|l|c|}
\hline BRAND & MAKER & FORMING METHOD & SYMBOL \\
\hline IG-11(R) & TOYO TANSO & Isostatic Molding & $\bigcirc$ \\
\hline H-451 & GLCC & Extrusion & \\
\hline TS-1240 & UCC & Extrusion & $\triangle$ \\
\hline G140A & TOKAI CARBON & Vibration Molding & $\Delta$ \\
\hline ASR-1RG & SI GR I & Vibration Molding & $\square$ \\
\hline P G X & UCC & Molding & \\
\hline A T J & UCC & Molding & $X$ \\
\hline ATR-2E & SI GR I & Extrusion & \\
\hline P3JHA & PUK & Molding & $*$ \\
\hline IG-11(S) & TOYO TANSO & Isostatic Molding & $\otimes$ \\
\hline V483T & SI GR I & Isostatic Molding & $\nabla$ \\
\hline
\end{tabular}

料内の結晶の層面が優先的に整列する方向， すなわちwith-grain方向 $(/ /)$ と, とれに垂直

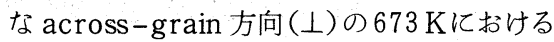
熱膨張係数の比より求めた。また黒鉛化度は, 各黒鉛材料の層面間隔よりWarren ${ }^{2)} の$ 黒鉛 化度の式を用いて求めた。なお以下の本実験 結果では，特に異方性問題に注目する場合を のぞいては用いた試料が比較的等方的なため に, with-grain, across-grainの物性值を 区別せずに同一の図面上に示すとととした。

\section{1 気孔率之諸物性}

Fig. 1 は気孔率 $\varepsilon$ と各銘柄のヤング率 $E$ との関係を示したあのであり，黒鉛材料の

張, 圧縮試験における歪速度は各々, 引張試験が $4.2 \times$ $10^{-4} \mathrm{sec}^{-1}$, 圧縮試験が $6.9 \times 10^{-4} \mathrm{sec}^{-1}$ である。

\section{2 ヤング率測定}

ヤング率は, 超音波伝播速度法により測定した。用い た発振子は $5 \mathrm{MHz}$ の水晶発振子であり, ての超音波の 縦波速度を測定し, 次式により計算した。

$$
\begin{gathered}
E=\rho v^{2} \times 10^{-6} \\
E: \text { ヤング率 }(\mathrm{GPa}) \\
\rho: \text { 密度 }\left(\mathrm{g} / \mathrm{cm}^{3}\right) \\
v: \text { 伝播速度 }(\mathrm{m} / \mathrm{sec})
\end{gathered}
$$

\section{3 電気比抵抗の測定}

電気抵抗は, 直径 $6 \phi$, 長さ $60 \mathrm{~mm}$ 形状の試験片によ り, ポテンションメーターを用いて 4 端子法により測定 した。

\section{3. 結果と考察}

Table II に本実験に用いた各種黒鉛材料の嵪密度, 黒 鉛化度, 異方性因子を示す。乙の異方性因子は, 黒鉛材

Table II A list of bulk densities, anisotropic factors and graphitization parameters by Warren for graphites used in the experiments.

\begin{tabular}{|l|c|c|c|}
\hline BRAND & $\begin{array}{c}\text { BULK DENSI- } \\
\text { TY }\left[\mathrm{g} / \mathrm{cm}^{3}\right]\end{array}$ & $\begin{array}{c}\text { ANISOTROPY } \\
\text { FACTOR (CTE) })\end{array}$ & $\begin{array}{c}\text { GRAPHITIZATION } \\
\text { FACTOR } P_{1}\end{array}$ \\
\hline IG-11(R) & 1.748 & 1.08 & 0.8663 \\
\hline H- 451 & 1.741 & 1.17 & 0.8663 \\
\hline TS-1240 & 1.760 & 1.10 & 0.8895 \\
\hline G140A & 1.662 & 1.18 & 0.9186 \\
\hline ASR-1RG & 1.804 & 1.15 & 0.8663 \\
\hline P GX & 1.735 & 1.15 & 0.9070 \\
\hline ATJ & 1.784 & 1.36 & 0.8779 \\
\hline ATR-2E & 1.807 & 1.07 & 0.8721 \\
\hline P3JHA & 1.729 & 1.09 & 0.9070 \\
\hline IG-11(S) & 1.760 & 1.08 & 0.8663 \\
\hline V483T & 1.773 & 1.15 & 0.8779 \\
\hline
\end{tabular}

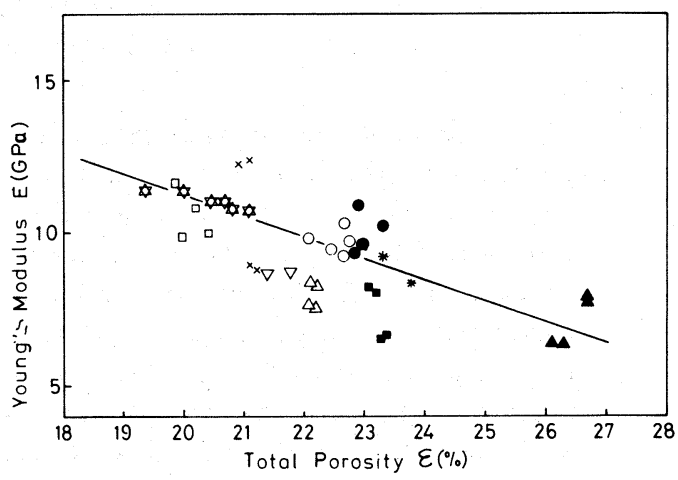

Fig. 1 Porosity vs Young's modulus of graphites diagram showing decrease in Young's modulus with increasing porosity.

with-grain 方向之across-grain 方向のヤング率を区 別せずに示してある。また気孔率は各黒鉛材料の嵩密度 と理論密度より求めた。乙の図より明らかなように, ヤ ング率は気孔率の増加之ともに減少する傾向が見うけら れる。乙の傾向はHutcheon ${ }^{4)}$, Yamaguchi ${ }^{5)}$ らの結果と一致している。しかしながら彼等 の結果が同一原料より作製された黒鉛材料の ヤング率に及ぼす気孔率の影響を示すのに対 し，本実験では原料すなわちコークス，その 粒径，ピッチ，焼成温度，成形方法等の異な る材料間の比較であり，それにあかかわらず 同様の傾向が認められるのは興味深い。さて, 黒鉛材料内部に打ける気孔は，粒内気孔と粒 間気孔に分けられる。粒内気孔はフィラー中 に最初加存在しているものと，後优べる 熱応力の緩和機構として生じる層面間でのデ ライミィネーション(層面はくり)に因るあの とがあり, 粒間気孔はバインダーの炭化に際 して生じるあのである。したがって上記の粒 
径, 焼成温度, および成形時の加圧圧力の相違は，乙れ ら気孔量に影響するとととなる。さらにヤング率は一般 に物体内に含まれる介在物の量之形状 ${ }^{7)}$ に依存する。 ここで気孔はヤング率が 0 の介在物と見なされるために， これら気孔率の増加とともにヤング率は減少するものと 考えられる。また, 後に述べるうに黒鉛化度にも黒鉛 材料のヤング率は関係する。なお Fig. 1. 亿示されるヤン グ率 $E$ と気孔率 $\varepsilon$ との相関関係を一次式で表わされるも のよして最小二乗法により求めると,

$$
E=23.4 \times 10^{9} \times(1-2.69 \varepsilon) \quad \mathrm{Pa}
$$

となる。乙とで $\varepsilon=0$ のときのヤング率は $23.4 \mathrm{GPa}$ とな り, Price ${ }^{8)}$ が単結晶のコンプライアンスを用い, 無気 孔性多結晶黒鉛材料の弾性率を理論的に求めた式で，等 方体とした場合のヤング率と良い一致を見ている。

Fig. 2 に $673 \mathrm{~K}$ に拈ける熱膨張係数 $\alpha$ と気孔率 $\varepsilon$ の 関係を示す。Fig. 2 より, 気孔率の増加とともに熱膨張 係数 $\alpha$ は減少する傾向, すなわち熱膨張係数が気孔率に 対して負の傾を有するととが判る。図中の同一銘柄黒鉛 材料におけるデーターのバラツキは, 熱膨張係数 $\alpha$ の小 さなものが with-grain 方向，大きなあのが acrossgrain 方向の試料に対応する。熱膨張係数 $\alpha$ を支配する 因子としては, 結晶の結晶化度, 配向性, およびバルク 中に存在する気孔があり，乙れらが熱膨張係数之相関が あるてとはすでに明らかとなっている ${ }^{5,9 \sim 12)}$ 。そしてて れらの結果は本実験の傾向と一致している。しかしなが ら先の報告が多くの場合その試料製造方法が同一のもの どうしで気孔率の効果を比較しているのに対し, 本実験 では各銘柄間で結晶粒度, バインダー量, 成形法等が異 なるにもかかわらず，熱膨張係数は気孔率の減少ととも に増加するという傾向で整理できる点を強調したい。な 扣熱膨張係数 $\alpha$ と気孔率 $\varepsilon$ との相関関係を一次式として

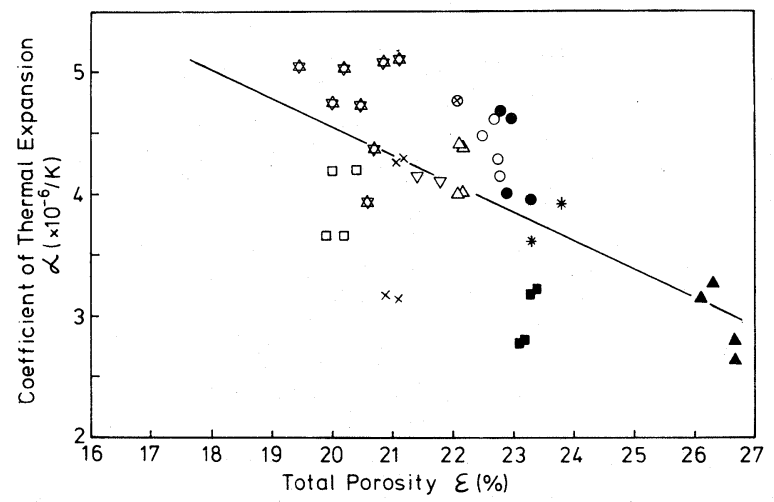

Fig. 2 Thermal expansion coefficients of graphites vs porosity diagram showing decrease in thermal expansion coefficient with increasing porosity.
最小二乗近似を行なうと，

$$
\alpha=9.15 \times 10^{-6} \times(1-2.52 \varepsilon) \quad 1 / \mathrm{K}
$$

となる。乙てで $\varepsilon=0$ における $\alpha$ は $9.15 \times 10^{-6}$ となり 等方体として平均化した熱膨張係数 $9 \times 10^{-6^{13)}}$ に極めて 良い一致を見る。

次にFig. 1 とFig. 2 の両者を比較すると次のことが明 らかとなる。すなわち，大きな熱膨張係数を有する黒鉛 材料は，比較的大きなヤング率を有するということであ る。とのととは同一の黒鉛成形品ロッドにおいて試料採 取位置によりヤング率, 熱膨張係数が異なり, ヤング率 の大きなあのほど熱膨張係数は大きい傾向にあるという 報告 ${ }^{5)}$ と一致する。しかしながら各銘柄間で製造方法等 が異なるにもかかわらず，先の報告と同様な傾向になる ことは黒鉛材料としての一つの特徴となろう。

ここでヤング率, 熱膨張係数, 気孔率の相関性につい て考える。多結晶黒鉛材料はほぼ $3000 \mathrm{~K}$ 近い温度で黒 鉛化処理される。乙の時, 成形時に生じた材料内部の残 留応力は, 高温に怙けるクリープによって緩和されるで あろう。冷却時には, 結晶の層面方向 ( $a$ 軸) とこれに垂 直な方向 ( $c$ 軸) に熱膨張係数，および弾塑性変形特性に 著しい差 ${ }^{6)}$ があり，しかも結晶がランダムに配列し互い に拘束しているため, 熱応力が発生する。ての熱応力を 緩和するために層面でのすべりすなわち塑性緩和が生じ, さらには層面間でデラミィネーションが起とる。これら 層面でのすべりおよびデラミィネーションの程度は黒鉛 化度と密接に関係するものと考えられる。すなわち黒鉛 化度の高いむのほどその結晶はより完全結晶に近いむの となり，層面間は完全なファンデルワールス結合状態之 なる。したがって黒鉛化度の高いものほど層面間でのす ベりが容易なものとなり，またデラミィネーションも生 じやすくなる。そしてデラミィネーションは微視的気孔 と考えられるため，黒鉛化度の高い屯のほど気孔率は大 きくなるととが予想される。Fig. 3 亿黒鉛化度を表わす Warren らのパラメーター $P_{1}{ }^{1,2)}$ と気孔率の関係を示す。 明らかに黒鉛化度の高いものほど気孔率は増大してい る。乙の結果は，黒鉛化妈理温度が高いものほど気孔率 が大きいという真田ら ${ }^{12)}$ の結果と一致している。また彼 等の水銀ポロシメトリィーの結果によれば，黒鉛化処理

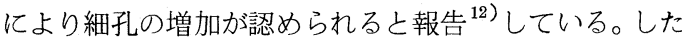
がっててれらの結果も, 熱応力の緩和機構として㗢くデ ラミィネーションが, 黒鉛化度の高い材料ほど黒鉛化 処理後の冷却時に数多く生じることを示唆するあので あると考える。ところで結晶子自身の格子熱膨張係数は Nelson ら ${ }^{17 \sim 19)}$ をはじめ多くの研究者により報告されて おり，完全な黒鉛結晶における $c$ 軸方向の熱膨張係数は $27 \sim 30 \times 10^{-6} / \mathrm{K}$ とみられている。一方黒鉛化度が低下 


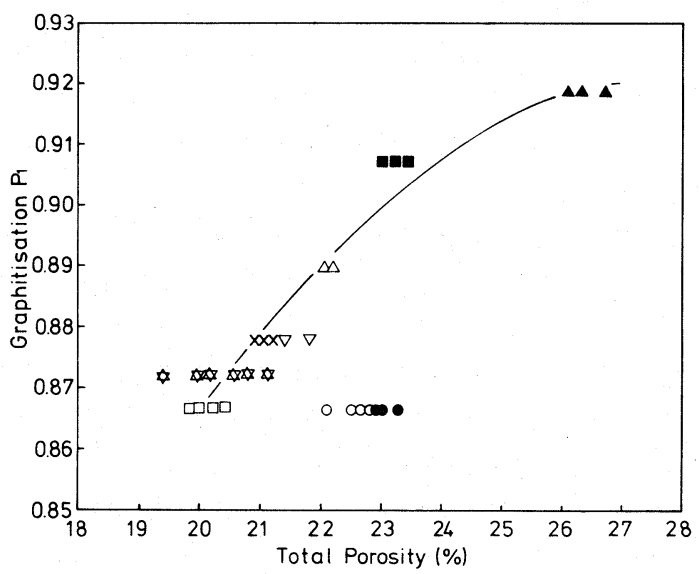

Fig. 3 Volume fraction of porosity vs degree of graphitization diagram showing increase in graphitization with decreasing the volume fraction of porosity.

すると格子熱膨張係数は黒鉛結晶の値よりあ小さくなり, Schiller ら ${ }^{20)}$ によれば $20 \times 10^{-6} / \mathrm{K}$ 程度あるいはそれ 以下になると思われる。したがって黒鉿化度の高い材料 ほど結晶の $c$ 軸方向の熱膨張係数が大きくなるととを考 えれば, バルクとしての熱膨張係数も黒鉛化度の高い屯 のほど大きくなると考えるのが一見妥当性のあるように 思われる。しかしながら実験事実は黒鉛化度の高いむの ほど熱膨張係数は小さくなる傾向を示している。これは すでに述べたように層面間でのすべりやデラミィネーシ ョンが黒鉛化度の高い材料ほど容易となるため, $c$ 軸方 向に比べて弾性係数の大きな $a$ 軸方向の熱膨張挙動がバ ルクの性質へ顕著に表われるあのと考えられる。一方ヤ ング率は, 黒鉛材料においては各結晶の微視的塑性変形 の影響を受ける。したがって，黒鉛化度の高い材料ほど 層面間でのすべりが容易であるために，ヤング率は低下 する。さらにデラミィネーションにより生じた気孔やバ インダーの炭化に際して生じた粒間気孔は欠陷 ${ }^{6)}$ とみな されるために，ヤング率の低下に結びつく。また気孔率 は, 黒鉛化度の高い屯のほど增大する。したがって, 気 孔率, ヤング率, 熱膨張係数の間には黒鉛化度を介して 相関関係が成立し，黒鉛化度の高い材料ほじ気孔率は大 きく, ヤング率, 熱膨張係数は小さくなる傾向になる。 さらに気孔率の多くを占める粒間気孔のヤング率, 熱膨 張係数に及ぼす影響も重要であり，乙のためヤング率， 熱膨張係数の減少をまねく。したがって黒鉛化度, 気孔 率の二つの因子の相乗効果が, 黒鉛材料のヤング率, お よび熱膨張係数の值を決定するととになるものと考えら れる。

Fig. 4 は熱膨張係数 $\alpha$ とヤング率 $E$ の相関関係を両対

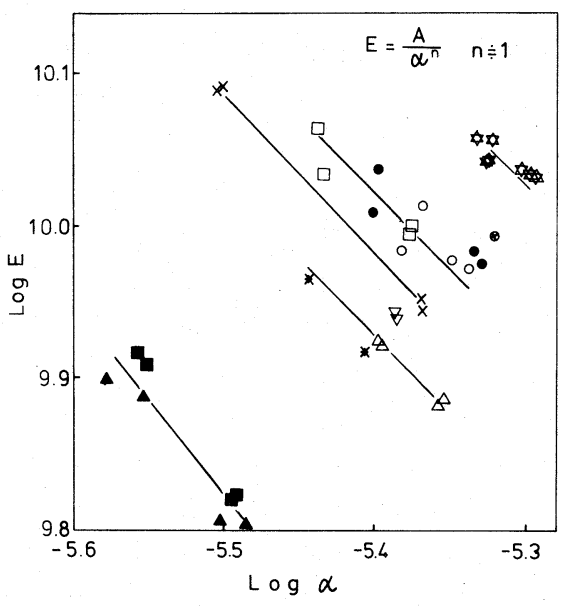

Fig. 4 Thermal expansion coefficient vs Young's modulus of graphites diagram.

数でプロットしたものである。次のととに注目したい。 測定した点がかなり広範囲に分散しているために相関関 係が明確でないが，グラフ左下から右上への相関性がう かがわれる。すなわち熱膨張係数の小さなあのほど左下 方に，大きなむのほど右上方にプロットされる傾向にあ る。また，乙の図で異方性を考慮すると，同一黒鉛銘柄 での with-grain 方向と across-grain 方向のプロット 点を結ぶ直線の傾きが, どの黒鉿銘柄でも等しく、ほぼ - 1 となるととである。つまり $\alpha E=A$ (定数)が成立す る。乙のととを確認するために，比較的異方性の大きな ATJ 黒鉛材料を試料として用い， $\alpha E=A$ (定数) が成立 するととを調べた。すなわち with-grain方向から角度 をつけて切り出した試料を作製し，乙れらの熱膨張係数 とヤング率を測定した。との結果をFig. 5 亿示す。眓か

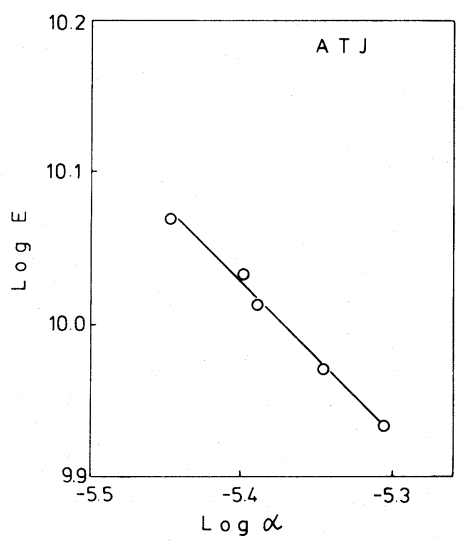

Fig. 5 Thermal expansion coefficient vs Young's modulus of ATJ graphite diagram. 
ら明らかなように測定点を結ぶ直線の傾きはー 1 となり， $\alpha E=A$ (定数)なる関係が成立している。以上のてとを 整理すると; 各黒鉛銘柄間では, 気孔率の小さい材料ほ ど図中 (Fig. 4) で右上万に位置する。さらに異方性のあ る同一銘柄黒鉛材料では, その試料の切り出し方向に無 関係に， $\alpha E=A$ なる関係式が成立する。次に各種黒鉛 材料のAについて検討する。Fig. 6 は Fig. 4 より得られ た各黒鉛材料の $A$ の值と気孔率の関係を示したあのであ る。図より，Aの值の大きなあのほど気孔率の少ないと とが判る。なお図中の曲線は，Eと $E$ に関する (1)，(2) 式より求めた。これは次式で示される。

$$
E \alpha=2.14 \times 10^{5} \times(1-2.69 \varepsilon) \times(1-2.52 \varepsilon)
$$

ここで $\varepsilon$ は気孔率である。この実験式が意味すること は, 黒鉛材料の気孔率 (嵩密度) を知れば $\alpha E$ が求まり, $\alpha E$ のうち一方を測定すれば他方のお抢よその值を求め るととができることである。

次に気孔率之電気比抵抗の関係を Fig. 7 に示す。一般 に電気抵抗は内部欠陥に敏感であるため, 気孔量, 黒鉛 化度などに関係するものと思われる。しかしながらFig. 7 に示すように気孔率と電気比抵抗に明確な相関は認め られない。また黒鉛化度と電気比抵抗の間には, Table II とFig. 7 を比較して屯はやり明確な相関関係は認めら れない。このことは, 一般の黒鉛化度と電気抵抗の関係 が, 本実験の様に各試料間で結晶粒径, バインダー量, 成形法の異なる場合には成立しないてとを意味している。

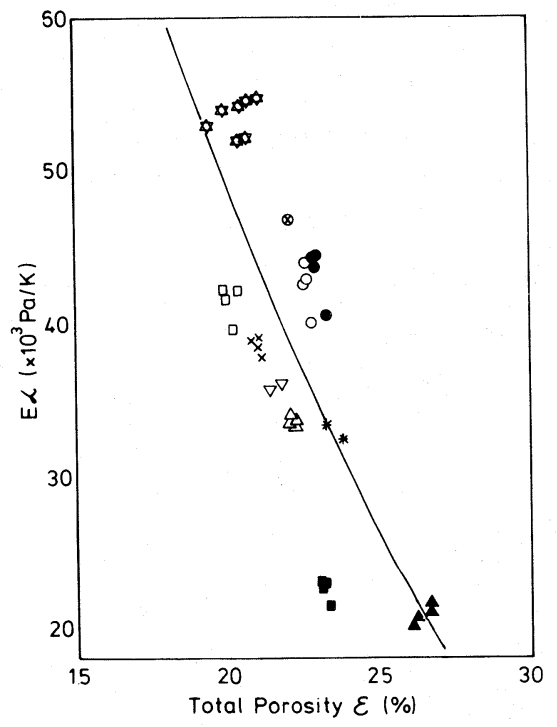

Fig. 6 The value of $\alpha E$ vs volume fraction of porosity diagram showing increase in $\alpha E$ with decreasing the volume fraction of porosity.

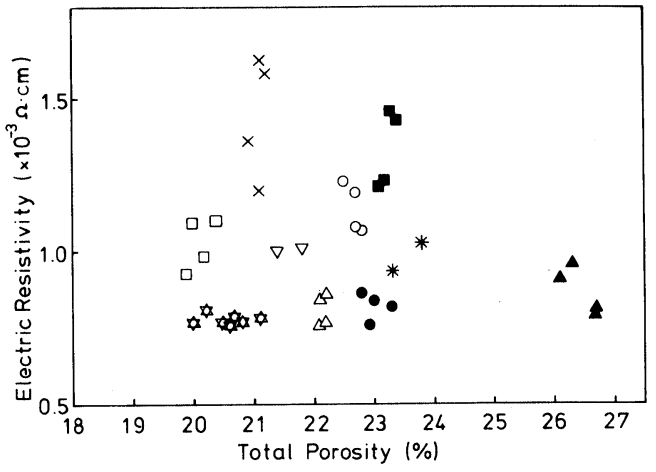

Fig. 7 Electrical resistivity vs volume fraction of porosity diagram.

次に電気比抵抗之各黒鉛材料の結晶粒径の関係につい て述べる。なお結晶粒径は, 各黒鉛メーカーのカタログ データーを参考とし, 軽いサーマルエチッチ後の表面観 察より決定した。

Fig. 8 に電気比抵抗と結晶粒径の関係を示す。次の様 な傾向が認められる。すなわち粒径の小さなものほど電 気比抵抗は大きく, 粒径の大きなむのは電気比抵抗が小 さい。これは以下の様に説明できる。黒鉛材料の製造過 程で混合されるバインダーの量は，ある一定の厚さで粒 をとりかてむ様に配合される。したがって, 結晶粒径の 小さなものほどバインダーの結晶粒体積に対する相対量 が大きくなる。このため結晶粒の小さいものほど諸物性 にバインダーの性質がより現われることになる。一般に バインダーは炭素材料に近い性質を有するためその電気 比抵抗は黒鉛化した材料に比べて大きい。すなわち炭素 材料の電気比抵抗はほぼ $4 \sim 6 \times 10^{-3} \Omega \cdot \mathrm{cm}$ と黒鉛材料 に比べて3〜5倍程度大きなものとなっている。このた め結晶粒の小さなものほどてのバインダー量の体積率が

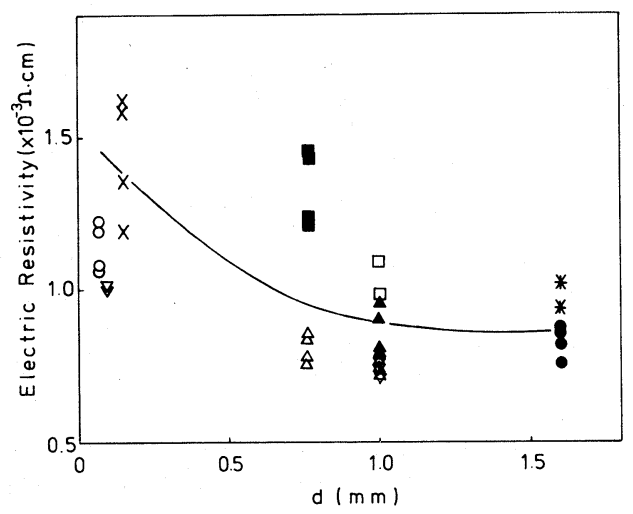

Fig. 8 Electrical resistivity vs grain size diagram showing increase in grain size with decreasing the electrical resistivity. 


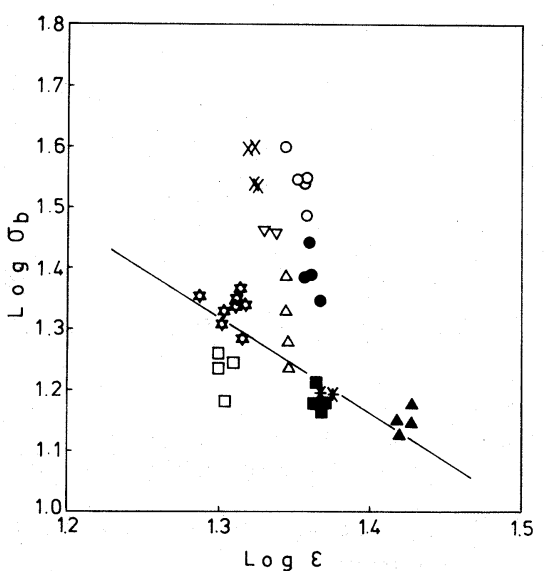

(a)

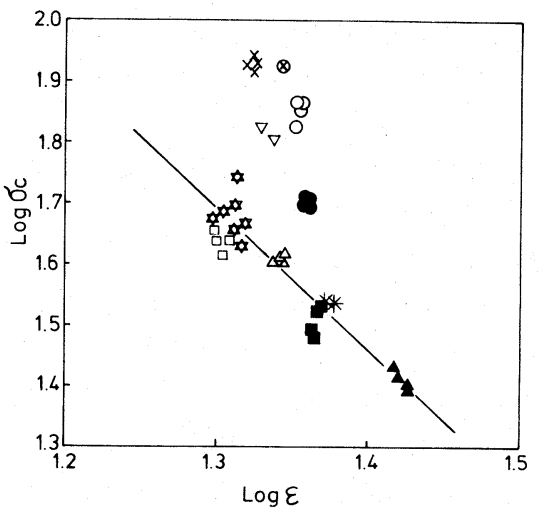

(b)

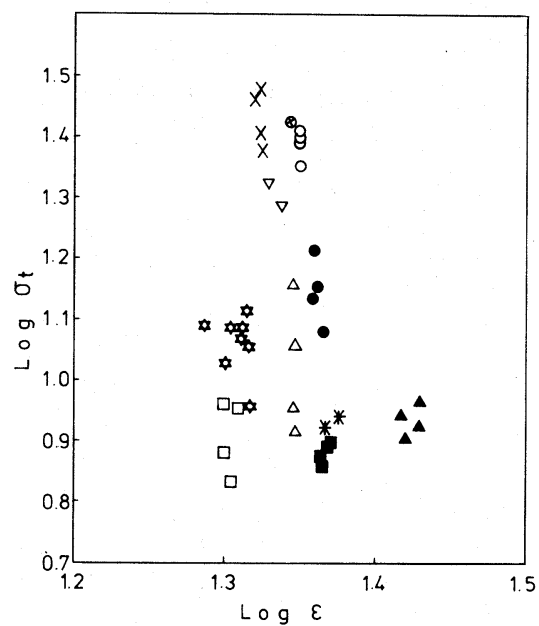

(c)

Fig. 9 Mechanical properties vs volume fraction of porosity diagrams, (a) bending strength vs volume fraction of porosity, (b) compressive strength vs volume fraction of porosity, and (c) tensile strength vs volume fraction of porosity.
大きいために，電気比抵抗は大きくなるあのと考えられ る。

次に気孔率之機械的性質について述べる。気孔率と曲 げ強度についてはHutcheon $ら^{4)}$ が実測值から経験的に 導いた関係式；曲げ強度 $\sigma_{\mathrm{b}}$ は $\sigma_{\mathrm{b}} \propto \varepsilon^{-16}$ なる式を示して いる。Fig. 9 (a)，（b)，（c）に曲げ強度と気孔率，圧 縮強度と気孔率, 引張強度と気孔率の関係を示す。Fig. 9 (a)の曲げ強度と気孔率の関係には, 先の $\sigma_{\mathrm{b}} \propto \varepsilon^{-1.6}$ な る式を直線で示してある。図より $\times, \bigcirc, \nabla て ゙$ 示した結 晶粒の小さな黒鉛材料を除けば，乙の関係式は気孔率と 曲げ強度の関係を良く表わしていると思われる。Fig. 9 (b)の気孔率之圧縮強度の関係にあやはり結晶粒の小さ い黒鉛材料， $\times, \bigcirc, \otimes, \nabla て ゙$ 示したものを除けば，圧 縮強度 $\sigma_{\mathrm{c}}$ と気孔率 $\varepsilon$ の間には $\sigma_{\mathrm{c}} \propto \varepsilon^{-2}$ なる関係が成り立 つととが判る。しかしながら Fig. 9 (c) の気孔率と引張 強度の関係には，明らかな相関は見い出せない。Fig. 10 亿引張強度と結晶粒径の関係を示す。これによると 引張強度は結晶粒径に依存し, 粒径の小さいむのほど 引張強度は増加することを示している。つまり引張強度 は気孔の量に関係せずに，結晶粒の大きさに依存してい る。

以上より，本実験に用いた黒鉛材料の引張強度は気孔 率之無関係である事が判った。しかしながらこの結果は 引張強度が気孔量化依存するという従来の考え方を否定 するものではない。すなわち同一粒径で気孔率のみを大 きく変えた試料では, 引張強度の気孔率依存性か認めら れるであろう。本実験ではTable II に示されるように比 較的気孔量の等しい黒鉛材料を用いたために, 引張強度 に対する粒度依存性が強く現わ机たものと考える。そし ててのことは黒鉛材料の引張破壊に対する内部欠陷の大 きさが，結晶粒度に依存するととを示唆するものであ る。

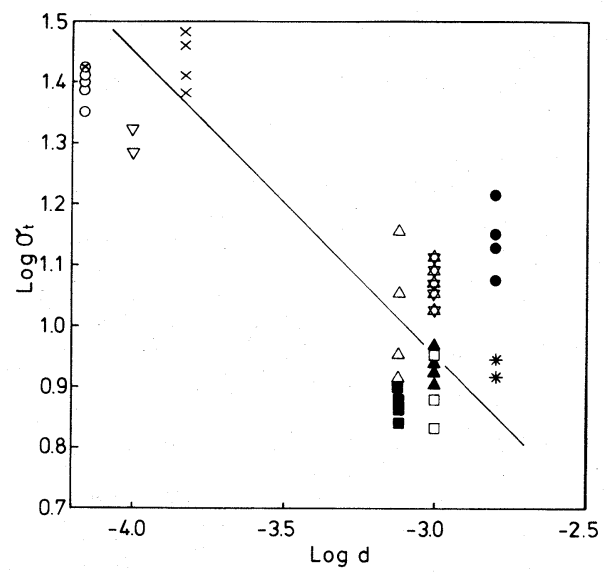

Fig. 10 Tensile strength vs grain size diagram. 


\section{2 機械的性質間の相関}

Fig. 11（a），(b)，（c）に引張強度と曲げ強度，曲げ 強度と压縮強度, 引張強度と圧縮強度の関係を示す。す べての図に良い相関関係が認められる。各々の関係式を 求めると, (a)より引張強度 $\sigma_{\mathrm{t}}$ と曲げ強度 $\sigma_{\mathrm{b}}$ の間には,

$$
\sigma_{\mathrm{t}}=0.87 \sigma_{\mathrm{b}}-5.82
$$

なる関係が成立する。また $(\mathrm{b})$ より曲げ強度 $\sigma_{\mathrm{b}}$ と圧縮 強度 $\sigma_{\mathrm{c}}$ の間には,

$$
\sigma_{\mathrm{b}}=0.46 \sigma_{\mathrm{c}}+0.09
$$

また $(\mathrm{c})$ より引張強度 $\sigma_{\mathrm{t}}$ と王縮強度 $\sigma_{\mathrm{c}}$ の間には,

$$
\sigma_{\mathrm{t}}=0.40 \sigma_{\mathrm{c}}-6.55
$$

なる関係式が成立する。な拉位はすべて MPaである。 (4)，（5）式より引張強度 $\sigma_{\mathrm{t}}$ を求めると,

$$
\sigma_{\mathrm{t}}=0.40 \sigma_{\mathrm{c}}-5.74
$$

となり (6) 式と比べて約 $0.8 \mathrm{MPa}$ の相違がある。このた め正確な值は求まりにくいが, 引張強度, 王縮強度, 曲 げ強度のうち一つを知れば他の二つの捛およその值が求 まることになり，実用上便利であろう。

\section{3 異方性}

Fig. 12 は異方性黒鉛材料における基底面が優先的に 並ぶ方向すなわち with-grain 万向 (//) と, 乙れに垂直 な across-grain方向 $(\perp)$ の物性值の比についてま亡め たものを示す。（a）は熱膨張係数の比とヤング率の比,

(b)に電気比抵抗の比とヤング率の比の関係を示す。多 結晶黒鉛材料の異方性は結晶の $a$ 軸方向が材料成形過程 で加圧軸に対し垂直方向へ優先的に配列するととに起因 する。したがって単結晶で $a$ 軸方向と $c$ 軸方向の物性值 に差のあるものほよ゙，多結晶黒鉛材料の巨視的異方性を 示すととになる。Fig. 12 (a)の熱膨張係数の比 $\left(\alpha_{\perp}\right)$ $\left.\alpha_{/ /}\right)$とヤング率の比 $\left(E_{/ /} / E_{\perp}\right)$ の間には,

$$
d\left(\alpha_{\perp} / \alpha_{\prime \prime}\right) / d\left(E_{/ \prime} / E_{\perp}\right)=0.92
$$

なる関係が成立する。乙のことは, 結晶の $a$ 軸方向之 $c$ 軸方向の両者の物性の巨視的物性に現われる比が, ヤン グ率の異方性の方が熱膨張係数の異方性よりあ顕著であ るととを示唆している。さらにFig. 12 (b) の両者の間に は，およそ次なる関係が成立する。

$$
d\left(\Omega_{\perp} / \Omega_{/ /}\right) / d\left(E_{/ /} / E_{\perp}\right)=0.76
$$

この関係むやはりヤング率の異方性の方が電気比抵抗の 異方性よりも，巨視的異方性に強く現われることを示し ている。単結晶の電気比抵抗の異方性は $a$ 軸方向に比へ て $c$ 軸方向が $10^{4}$ 倍 ${ }^{15)}$ ほど大きく, これは弾性率の異方 比よりもはるかに大きい。しかしながら巨視的異方比に は弾性率の異方性の方が顕著に現われているが，ての 原因については今のとてろ明らかでない。さらに( $\Omega_{\perp} /$ $\left.\Omega_{/ /}\right)$と $\left(\alpha_{\perp} / \alpha_{/ /}\right)$との関係を調べた他の報告 ${ }^{16)}$ と, 本 実験より得られた結果は良い一致を示した。

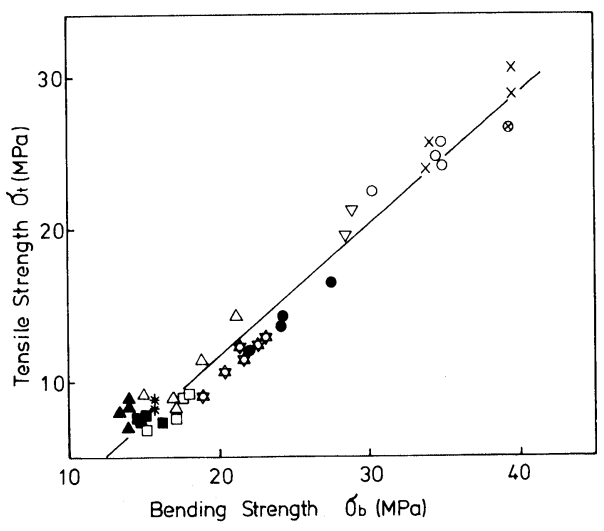

(a)

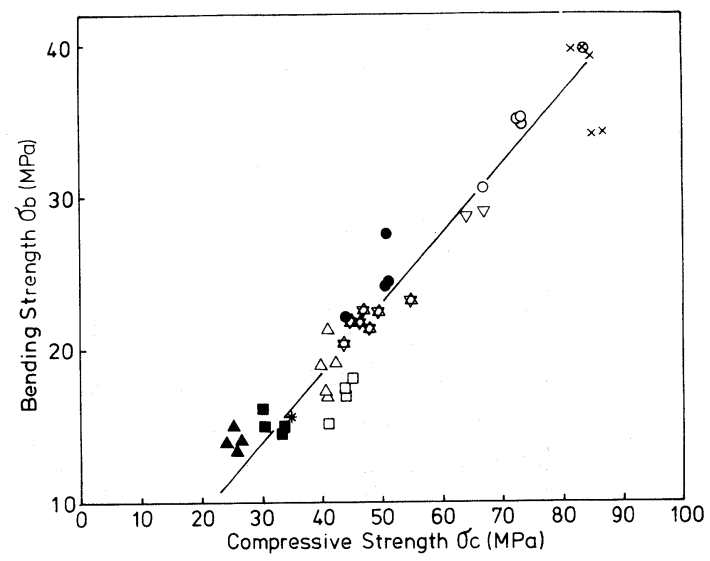

(b)

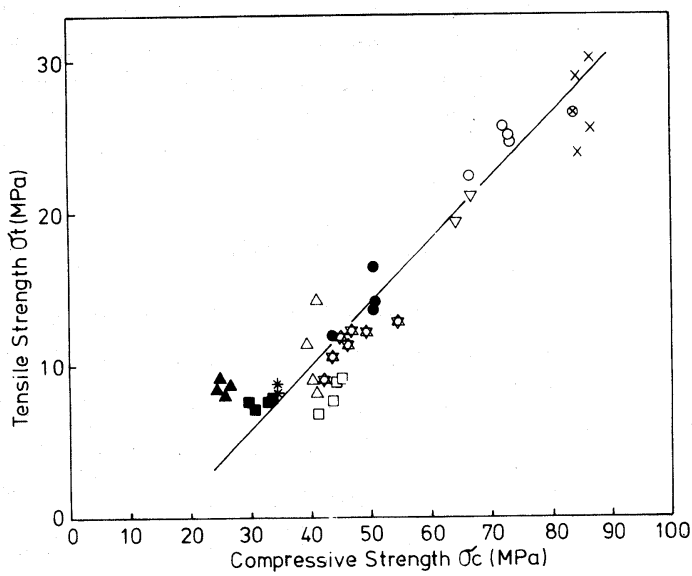

(c)

Fig. 11 (a) Tensile strength vs bending strength, (b) bending strength vs compressive strength, and (c) tensile strength vs compressive strength diagrams showing good relationships between them. 


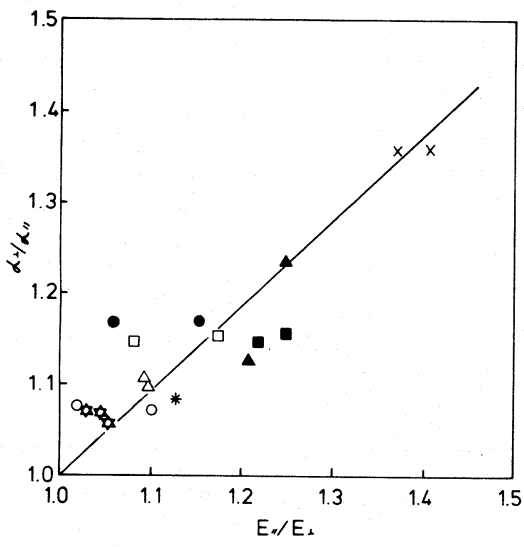

(a)

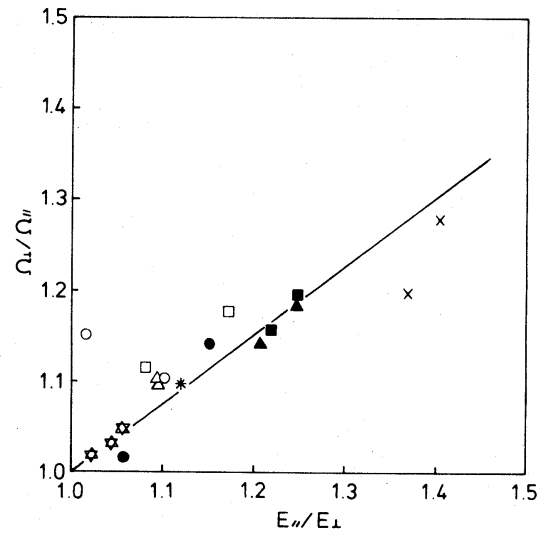

(b)

Fig. 12 (a) Thermal expansion vs Young's modulus diagram and (b) electrical resistivity vs Young's modulus diagram, showing the effect of anisotropy on physical properties of graphites.

\section{4. 結言}

多結晶黒鉿材料 10 銘柄の物理的, 機械的性質, すなわ ち引張強度, 圧縮強度, ヤング率, 熱膨張係数, 電気抵 抗，気孔率，黒鉛化度，を調へ，乙れらの間の相関関係 を明らかとした。本実験より得られた結果をまとめると,

（1）十ング率および熱膨張係数は気孔の体積率に依存 し, 気孔率の増加に伴い減少する傾向にある。また, 気 孔率は黒鉛化度と密接に関係し, 黒鉛化度の良いものほ ど気孔率が増加する傾向にある。

（2）ヤング率と熱膨張係数の間には，ヤング率の大き な黒鉛材料ほど熱膨張係数む大きい傾向にある。さらに 同一黒鉛材料で翼方性を有するあのは，その切り出し方 向によらず熱膨張係数 $\alpha$ とヤング率 $E$ を用いて， $\alpha E=$
一定なる関係が成立する。またての $\alpha E$ の值は各銘柄黒 鉛材料の気孔率に依存する。

（3）電気比抵抗は, 黒鉛材料の結晶粒度に依存し, 粒 の細かいあのほどその抵抗值は大きい傾向にある。この ことは, 微粒黒鉛材料ほど電気抵抗におよぼすバインダ 一の影響が大きいと考えられる。

(4) 曲げ強度 $\sigma_{\mathrm{b}}$, 圧縮強度 $\sigma_{\mathrm{c}}$ は, 気孔率 $\varepsilon$ 之関係し, 一部の微粒黒鉛材料をのぞけば経験的に, $\sigma_{\mathrm{b}} \propto \varepsilon^{-16}$, $\sigma_{\mathrm{c}} \propto \varepsilon^{-2}$ なる関係式で整理できる。

（5）引張強度 $\sigma_{\mathrm{t}}$, 圧縮強度 $\sigma_{\mathrm{c}}$, 曲げ強度 $\sigma_{\mathrm{b}}$ の間には 良い相関関係が認められた。したがってての值のうち一 つを測定すれば，他の二つのおおよその值は次なる経験 的関係式によって求めるととが可能である。

$$
\begin{aligned}
& \sigma_{\mathrm{t}}=0.87 \sigma_{\mathrm{b}}-5.82, \\
& \sigma_{\mathrm{b}}=0.46 \sigma_{\mathrm{c}}+0.09, \\
& \sigma_{\mathrm{t}}=0.40 \sigma_{\mathrm{c}}-6.55
\end{aligned}
$$

なお単位は $\mathrm{MPa}$ である。

\section{文献}

1) C. R. Houska and B. E. Warren, J. App. Phys. 25 (1954) 1503

2) B. E. Warren, Proc. 1st and 2nd Conf. Carbon (1956) 49

3) S. Mrozowski, Proc. 1st and 2nd Conf. Carbon (1956) 195

4) J. M. Hutcheon and M. S. T. Price, Proc. 4th Conf. Carbon (1960) 645

5) 山口, 工業化学雑誌, 62, 1719, (1959)

6) W. N. Reynolds, Physical properties of graphite, Elsevier Publishing (1968), p. 81

7) J. D. Eshelby, Proc. Roy. Soc. (London) 241A (1957) 367

8) R. J. Price, Phil. Mag. 12 (1965) 561

9) S. Mrozowski, Proc. 1st and 2nd Conf. Carbon (1956) 31

10) L. D. Loch and A. E. Austin, Proc. 1st and 2nd Conf. Carbon (1956) 65

11) A. L. Sutton and V. C. Howard, J. Nucl. Mater. 7 (1962) 58

12) Sanada et al., Tanso 1972 [No. 70] 71

13) W. N. Reynolds, Physical properties of graphite, Elsevier Publishing (1968), p. 85

14) W. N. Reynolds, Physical properties of graphite, Elsevier Publishing (1968), p. 81

15) W. N. Reynolds, Physical properties of graphite, Elsevier Publishing (1968), p. 91

16) 松尾, JAERI-M，8367，(1979）35

17) J. B. Nelson and D. P. Riley, Proc. Phys. Soc. London 57 (1945) 477

18）松山英太郎, 炭素 1958 [No. 7] 12

19) 白石 稔, 他, 工化 74, (1971) 1331

20) C. Schiller, J. Mering, P. Cornuault et F. Du. Chaffault, Carbon 5 (1967) 385 